\title{
The Fractured Messaging of the National Collegiate Athletic Association and Its Members in Response to COVID-19
}

\author{
Timothy Mirabito \\ Robin Hardin \\ Ithaca College \\ University of Tennessee
}

\author{
Joshua R. Pate \\ James Madison University
}

\begin{abstract}
The sports world's near universal moratorium in response to the COVID-19 pandemic was abrupt and unprecedented. From professional leagues to youth sports, doors were closed to competitions and events to help stop the spread of the coronavirus. The hiatus began at one of the busiest times on the calendar for sport, with the National Basketball Association and National Hockey League seasons concluding; the Women's National Basketball Association and National Football League drafts taking place; Major League Baseball's spring training nearing its conclusion; the Professional Golf Association and Ladies Professional Golf Association Tours starting their seasons; and the National Collegiate Athletic Association's marquee events, the Division-I men's and women's basketball tournaments, set to begin. The suddenness of the interruption was met with a need by the various sport entities to engage their public with information about their respective responses. The statements that emerged on or after March 12— "the day the sports world stopped"-were not all the same. Many of the statements, in fact, were quite different. That was especially the case with the National Collegiate Athletic Association, whose governance structure and messaging practices hindered their ability to have a uniform response. The purpose of this essay was to examine the public messaging of sport leagues and organizations and to discuss the effectiveness (or ineffectiveness) of those public statements.
\end{abstract}

Keywords: coronavirus, crisis, NCAA, pandemic response, public messaging

Dr. Anthony Fauci, director of the National Institute of Allergy and Infectious Diseases and one of the faces of the White House Coronavirus Task Force charged with spearheading the United States' response to COVID-19, said in an interview

Mirabito is with Ithaca College, Ithaca, NY, USA. Hardin is with the University of Tennessee, Knoxville, TN, USA. Pate is with James Madison University, Harrisonburg, VA, USA. Mirabito (tmirabito@ithaca.edu) is corresponding author. 
on April 15, 2020, that he believed sports could return in the summer of 2020 if they implemented comprehensive health and safety accommodations (Hamby, 2020). Two of the most notable alterations that he suggested were substantial amounts of testing and games being played "behind closed doors" (Cancian, 2020, para 1). Testing would likely be within the capacity of major sport leagues, as long as tests were made available to them (Goldman, 2020). A point of contention early in the response to the coronavirus outbreak, ironically, was the National Basketball Association's (NBA) ability to secure tests for players who demonstrated symptoms of COVID-19, while other Americans did not appear to have similar access (Zillgitt, 2020). Fauci's second recommendation of physically sequestering fans from games and events would present another unprecedented requirement in a response that has already realized unparalleled circumstances.

Fauci, operating in arguably one of the most vitriolic political climates in modern American history (Nicholas \& Friedman, 2020), has been both a governmental mainstay (serving under six presidents) and an important informational voice for the American public (Gmoser, 2020). He has also supplied a bit of truth serum to an administration's crisis response that has drawn substantial criticism for its general incoherence (Nicholas \& Friedman, 2020). Fauci has relied on objective, empirical data to support his public statements, often resisting speculation. His approach squares precisely with what Coombs, Holladay, and Claeys (2016) suggested a crisis communication response should be: contextual and responsible. It has also set a standard for the forward-facing communication attempts of sport leaders in North America as their leagues and organizations continue to navigate the uncertainty of this pandemic or, more specifically, for how their specific sport entity communicates its intentions to move forward.

The magnitude of this pandemic's effect on instrumental facets of life (economic, health, social, emotional, etc.) will likely go undetermined for years, thus making it difficult to compare to other seminal crises that have impacted sport on a large scale. A moratorium across all sports, paired with an indeterminant schedule ahead, lacks specific precedence among North American sports. In fact, it illuminates some of the challenges league executives and communication directors have encountered historically. President Franklin D. Roosevelt, for instance, wrote then-Major League Baseball (MLB) Commissioner Judge Kenesaw Mountain Landis "The Green Light Letter" on January 15, 1942. Roosevelt implored Landis to play the 1942 baseball season despite the involvement of the United States in World War II so that Americans might "have a chance for recreation and for taking their minds off their work" (Cox, 2020, para 3). MLB played a complete season (154 games) that year.

Roosevelt's logic was that sport served as a distraction in the face of crisis-an antidote to news filled with constant despair (Brown, 2004). It was the same basis that led the National Football League (NFL) to play a full slate of games on Sunday, November 24, 1963, two days after President John F. Kennedy was assassinated in Dallas. The White House, in this case press secretary Pierre Salinger, once again leaned on sport to help society cope with tragedy (King, 1993). Pete Rozelle, a stalwart commissioner of the NFL who served in that role for 29 years, acquiesced to the White House's request and ordered the games be played. He later said that it was the biggest regret of his career (Chidester, 2009). That regret served as a benchmark for Rozelle's protégé, Paul Tagliabue, who faced a similar decision to play or cancel games after the terrorist attacks of September 11, 2001 (9/11; Brown, 2004). Tagliabue and the NFL, 
along with MLB, college sports, and most other major sporting enterprises, went on hiatus for a week following 9/11. The decision to postpone games immediately following the attacks has been generally lauded by historical measure (Mirabito, 2013), but deliberately suspending games was atypical for sport.

College athletics were charged with responding to these and other crises as well. For instance, college football's 1942 Rose Bowl was moved from Pasadena, California, to Raleigh, North Carolina, for fear of Japanese attack on the west coast after the United States officially engaged in World War II. Stanford won the men's basketball championship 3 months later in a somber, but relatively unaltered, National Collegiate Athletic Association (NCAA) tournament. Oklahoma and Nebraska played on Saturday, November 23, 1963, a day after JFK was assassinated. Most games, however, were postponed following Kennedy's assassination. The rivals played their scheduled event at the urging of then-Attorney General Robert Kennedy (Shatel, 2013). And almost all major Division I athletic events were postponed after 9/11, including the second week of the college football season. The NCAA, of course, has the unique challenge of existing across different sports, across different periods of the year, and across all regions of the country, which adds to the complexity of these extraordinary scenarios.

The irregular history of sport decision makers' ultimate resolutions to crisis response, compounded with the public reception of those choices, may be one of the few guiding standards the past can have on sport's coronavirus decisions. MLB demonstrated the capacity of sport to distract from the perils of war in 1942. The NFL realized that there is a "too soon" to play following national tragedy in 1963. And 9/11 afforded sport some assurances that the public can be patient with an interruption. The consistent thread through all of these decisions - and the many others that have affected sport-is a duality between decision and communication. Each of the aforementioned decisions about resuming games was grounded with reasoned guidance, seemingly heavily influenced by the social impact of the choices, and a consideration of public messaging that framed the sport's position for stakeholders. The decisions and communication are fundamental to the response to crisis, but who communicates this messaging is also important. For instance, former MLB Commissioner Bud Selig and Tagliabue were crucially present post-9/11, which gave credence to their respective sports' decisions not to play (Chass, 2001; King, 2014).

The purpose of this essay was to examine the responses of North American sport entities to the COVID-19 pandemic and the cancellation, postponement, or suspension of competition. This essay explores the fragmented reactions through public statements and press engagements, in hopes to identify optimal communication policy implementation in managing these situations. This work specifically focuses on the NCAA and its members, whose response was both susceptible to imprecision because of its governance structure and pertinent because of the timing that impacted both winter and spring sports.

\section{NCAA Governance}

The NCAA is composed of nearly 1,100 active member institutions across three divisions. Nearly 500,000 student-athletes compete in NCAA-sponsored sports, and the NCAA offers 90 national championships across its three divisions. The members 
are also organized into 142 conferences within the NCAA, with each conference offering competitions and championships for its members ("Composition and Sport Sponsorship of the NCAA Membership," 2020). An important aspect of the NCAA and the conferences is that membership is voluntary. They abide by the policies and rules set forth by the governance structure (NCAA Academic and Membership Affairs Staff, 2019; see Article 4 of the 2019-20 NCAA Division I Manual for a complete description of the organization's governance structure).

The NCAA has a full-time staff at its national headquarters, which includes a president. But the policymaking of the organization lies with the members through various administration structures. The Board of Governors oversees the organization as a whole and is composed of 21 members, consisting of university presidents and chancellors, as well as five independent members. The Board of Governors provides direction of the organization, which includes strategic planning, budget planning, and hosting the annual convention to address the concerns of the entire organization (NCAA Academic and Membership Affairs Staff, 2019).

The most prominent championship sponsored by the NCAA is the Division I men's basketball championship. Sixty-eight teams qualify for the tournament through automatic bids via conference championships, as well as at-large bids. The 67 games are played during a 3-week span each spring and generate nearly \$1 billion in revenue for the NCAA and its members (National Collegiate Athletic Association, 2019). The Division I men's ice hockey championship, as well as the Division I women's basketball tournament, Division I college baseball world series, and Division I softball world series also generate revenue and media attention, but pale in comparison to the men's basketball tournament. Member institutions do have some input into the tournament through representation on various administrative committees, but the NCAA is the primary overseer of the tournament.

The NCAA, however, has little to no input into the management and operation of the 31 Division I conference men's basketball tournaments. Those fall under the purview of the individual conferences. It is important to note that the conference tournaments are the primary means for determining participants in the NCAA tournament, so communication is critical between the NCAA staff and conference staffs.

Here within lies the recent communication breakdown between the NCAA and conferences that was brought to the forefront with the COVID-19 pandemic. There was also a communication gap between the conferences themselves, most notably the autonomous conferences within the NCAA (Atlantic Coast Conference [ACC], Big Ten, Big XII, Pac-12, and Southeastern Conference [SEC]). There is a somewhat working relationship among the conferences, but the conferences themselves are autonomous in their own right and can enact policies that are applicable only to their conferences. Conferences make their own decisions in regard to scheduling, conference championships, revenue distribution, and television contracts. Thus, the conferences do work in harmony, but still operate as individual entities.

\section{NCAA's Response}

At 4:15 p.m. Eastern Time Zone on Wednesday, March 11, 2020, NCAA President Mark Emmert released a statement that the NCAA was working with "public 
health officials" and their COVID-19 panel to ascertain the status of scheduled NCAA events. The statement read:

Based on their advice and my discussions with the NCAA Board of Governors, I have made the decision to conduct our upcoming championship events, including the Division I men's and women's basketball tournaments, with only essential staff and limited family attendance. (National Collegiate Athletic Association, 2020a, para 1)

An hour prior to the NCAA's announcement, the Ivy League announced it was canceling all of its athletic events for the remainder of the spring semester. Its statement read, “... the Ivy League Presidents are announcing their unanimous decision to cancel all spring athletics practice (sic) and competition through the remainder of the academic year" (Ivy League Athletics, 2020, para 1).

The day after both statements, players at the ACC men's tournament in Greensboro, North Carolina, and the SEC men's tournament in Nashville, Tennessee, were seen walking off the court to the news that their tournaments had been canceled moments before the games were set to begin those respective events. Meanwhile, Creighton and St. John's played the first half of their Big East men's basketball tournament game in Madison Square Garden in New York. The contrast of a game being played in New York while all other major conferences canceled their games, with the Ivy League, more significantly, canceling its entire spring sport season, was stark. By the end of the first half, in part due to the optics of the juxtaposition, Big East officials conceded that continuing to play was not appropriate and canceled the remainder of that game and tournament (Dellenger, 2020). At 4:07 p.m. on March 12, the NCAA "canceled the Division I men's and women's 2020 basketball tournaments, as well as all remaining winter and spring NCAA championships" (National Collegiate Athletic Association, 2020b, para 1).

The Big East, ironically, was one of the first conferences to subsequently cancel all athletic events through the remainder of the academic year. Their statement read: "The BIG EAST Conference has announced the cancellation of all Spring sport competitions effective immediately. This decision follows the recent NCAA announcement to cancel all winter and spring championships" (Big East Conference, 2020, para 1). Other conferences, like the American Athletic Conference (AAC) and the Sun Belt Conference, also decisively canceled or suspended competitions for the rest of the year immediately on March 12 (American Athletic Conference, 2020; Sun Belt Conference, 2020). The Big XII, Pac-12, and SEC - among others-canceled their winter sports competitions, but left open the possibility of continuing their spring seasons (Big 12 Conference, 2020a; Pac-12 Conference, 2020; Southeastern Conference, 2020).

Evidence of fractured messaging emanated from these decisions, with certain individual conferences abstaining from canceling their spring seasons. The NCAA canceled all spring sport championships (i.e., golf, tennis, baseball, softball, etc.), but not all conferences had made their decision on canceling their seasons and conference championship events. The Pac-12 and SEC, for instance, did not cancel their spring sports until March 14 (Pac-12 Conference, 2020; SEC, 2020). The Big XII did not officially cancel athletic events until March 29 (Big 12 Conference, 2020b). 
The response by the NCAA and its conferences lacked any uniformity and was disjointed during the 72-hr period when the cancellations began to be announced. The combination of varying responses from the governing body canceling potential postseason competitions, member conferences generating distinctly disparate logistical responses, and a lack of uniformity in the communication itself created a fragmented landscape littered with uncertainty about the status of sport for the NCAA. There was a communication gap that occurred within the NCAA as an organization, the member institutions, and their conference governing bodies.

\section{Other Major Sports' Responses}

The cover of the New York Post on March 12 read, "The day the sports world stopped" (Vaccaro, 2020). The imagery, set to a black backdrop, depicted the league logos from the National Hockey League (NHL), MLB, Major League Soccer (MLS), NBA, Professional Golf Association (PGA) Tour, and NCAA, with a moratorium status of play below each logo. The designations read, "paused," "canceled," "season delayed," or "suspended." Formula One, the National Lacrosse League (NLL), Ultimate Fighting Championship (UFC), XFL, and World Wrestling Entertainment Inc. (WWE) also released statements on March 12, alerting stakeholders to their playing status. It was the NBA, however, that not only preempted these releases on March 11, but took swift and declarative action in response to the COVID-19 outbreak, which earned the league praise (Golliver, 2020). Its entire statement read, "The NBA is suspending game play following the conclusion of tonight's schedule of games until further notice. The NBA will use this hiatus to determine next steps for moving forward in regard to the coronavirus pandemic" (National Basketball Association, 2020, para 2).

National Basketball Association Commissioner Adam Silver has been specifically commended for his decisive action, especially after it was found that multiple team owners objected to halting the season (Nesbitt, 2020). Silver acted proactively, consulted with notable health professionals, and responded decisively once he was informed of Utah Jazz player Rudy Gobert's infliction with the virus (Golliver, 2020). The NHL, whose season runs concurrent with the NBA's and naturally creates logistical parallels, was also given high marks for its response to the coronavirus. Sports Illustrated, in fact, noted that not a single team objected to NHL Commissioner Gary Bettman's recommendation that the league postpone its games indefinitely (Prewitt, 2020). The NBA and NHL have provided the gold standard among pundits over their handling of the crisis and the communication of their decisions.

The Ladies Professional Golf Association (LPGA) was one of the first organizations to have to address the impact of the coronavirus, as its early-season schedule was set in parts of Asia, which forced the association to cancel three events. Its first canceled event, the Honda LPGA Thailand, was scheduled to begin February 20 in Chonburi, Thailand. The first tour event in the United States was not scheduled until March 19 in Phoenix, Arizona. It did, however, release an official statement on March 12, informing the public that the next three events-including its first major-were also postponed. The PGA Tour, however, was one of the few organizations that proceeded with its schedule, playing the first round of 
the Players Championship in Ponte Vedra Beach, Florida, on Thursday, March 12. During a Golf Central telecast, LPGA Commissioner Mike Whan said the following:

If I'm being totally honest, I feel fairly confident we could probably play Phoenix. Maybe we could even play Carlsbad without our fans. But can I live with it if I'm wrong? If I'm wrong, I'll regret that the rest of my life. This is a decision I may not like, but I don't think I'll ever regret. I just wasn't willing to live with being wrong. (Mell, 2020, para 16)

The contrast was poignant and, later that evening, just before 10 p.m. Eastern Time Zone, the PGA Tour announced that it was canceling the remainder of the tournament (Professional Golf Association, 2020).

The NCAA had two significant disadvantages in contrast to these other leagues. First, college teams were in the midst of the most visible portion of their winter sports' season, with the men's and women's basketball postseasons in session, when sport collectively stopped. Second, the governance structure is inherently challenging to navigate within the NCAA, as opposed to other sports leagues with more clear-cut reporting structures. The NCAA is ostensibly toothless in administrating athletic events and implementing granular logistical directives. Leagues like the NBA, NHL, and LPGA have a specific hierarchy led by commissioners and executives that allows responses to crises to flow more efficiently-even if they are not always optimal.

\section{Discussion}

The range of nuance, even in the words chosen to describe the state of play across sports leagues_-"suspend" versus "postpone," for instance-indicates the subtle but important differences in the responses to the pandemic. And, certainly, the calendar gave certain leagues advantages over others with the quickly immersive nature of COVID-19. But of all the major sporting institutions tasked with formulating a response, and there were not many who were exempt, the NCAA emerged as one of the most fragmented - in large part due to its governance structure-when it came to its initial public messaging. The unfortunate byproduct of that is that this pandemic is laden with uncertainty that will continue to force sport entities and organizations to adjust and inform their stakeholders as schools look to plan for the fall 2020 semester and beyond. That dynamic is already emerging within the NCAA as public debate increases over the timeline for when colleges and universities will be able to return to physical classes. Bob Bowlsby, Big XII commissioner and member of the College Football Playoff Management Committee, was quoted in a conference call saying, "Our players are students. If we're not in college, we're not having contests" (Dodd, 2020, para 2). Mark Emmert has echoed that position in his public messaging. Emmert said in an interview, "If a school doesn't reopen, then they're not going to be playing sports" (Duncan, 2020, para 3).

There are gray areas in those statements. First, as was the case when the NCAA canceled its men's and women's basketball tournaments, that did not preclude teams or conferences from holding athletic events. The Big XII did not 
cancel spring sports until March 29, more than 2 weeks after the NCAA canceled spring sports. Second, different states and regions in the country began opening from shelter-in-place restrictions at different paces; some states never closed. Both Bowlsby and Emmert's statements mandated that students need to be on campus in order to play sports. If the University of Nebraska or the University of Iowa, two institutions that reside in states that did not impose strict stay-at-home directives, are back in the fall 2020, they meet that criteria. Would the NCAA prohibit them from seeking out playing partners that have also returned students to campus? Emmert said in that same interview,

Schools will probably have to re-start athletics at different times depending on their situation. Some teams may not be able to play a full schedule and the NCAA would have to figure out how that would affect the decision on which teams participate in championships. (Duncan, 2020, para 7)

There are schools, Clemson University and the University of South Carolina, for example, that are moving forward with intentions to play, albeit in modified stadium settings, in the fall (Cloninger \& Needelman, 2020). And given the unique governance structure the NCAA has, with autonomy among its member institutions and conferences, Emmert and the NCAA have little say over when and how member institutions return to play.

Cal State East Bay, a NCAA Division II member in Hayward, California, announced on May 12 that it is canceling all sports for the fall semester (Harding, 2020). The Mid-American Conference (MAC) has plans to hold sports in 2020-21, but will be canceling conference postseason tournaments for some sports and reducing the number of participants for other conference postseason tournaments (Boone, 2020). This is most likely a cost-saving move, as the pandemic has had a dramatic financial impact on college athletics. The University of TennesseeChattanooga announced that it will not schedule away competitions more than 150 miles away from campus and teams will travel the day of the competition and return after the competition. This is also tied to the financial constraints being encountered in college athletics (Megargee, 2020). The result of the current structure of the NCAA has individual schools, not the conferences they belong to, making decisions about their athletic participation, which further muddies the NCAA's response as a collective body.

The impact of all of these decisions in college athletics has a ripple effect throughout the organization. The fact that Cal State East Bay is canceling all fall competition also means that teams they were scheduled to play will be impacted. The cancellation of postseason tournaments in the MAC means the organizations and cities hosting those championships will now have to alter their plans. The student-athletes subsequently will not be able to compete for a postseason championship, and these decisions will impact how conference representatives will be selected for participation in NCAA championship events. The induced effects are almost endless. The underlying issue in all of this is that the members and conferences can make decisions without input or consent from the NCAA or other members of the organization. This creates a fractured communication structure in the organization and among its members. The autonomy afforded conferences and individual athletic departments serves the NCAA well in most 
day-to-day operations. When large-scale crises like a pandemic require uniform, responsible, and contextual responses (Coombs et al., 2016), however, the model seems less effective. This is a call to develop a more comprehensive plan to respond to a crisis situation and develop a consistent communication strategy.

\section{Conclusion}

This may be a watershed moment for college sports, comparable to the Georgia and Oklahoma lawsuit versus the NCAA in 1984 ("NCAA v. Board of Regents of the University of Oklahoma," 1984) to negotiate television rights and the establishment of the Bowl Championship Series in 1998. This moment, however, has highlighted the fragmented communication throughout the NCAA and its members. The issue that arises from this fragmentation is the lack of a coherent communication plan or strategy to respond to issues that impact the entire membership.

A review of the NCAA Division I Manual indicates there is no one associationwide group that is responsible for unified membership communication. Therefore, the result is fragmented and often conflicting messages sent by the NCAA, conferences, and member institutions during situations like the COVID-19 pandemic. Government and university officials have made statements that are not congruent with statements by conference commissioners, athletic directors, and coaches. Statements by athletic representatives have been in conflict with one another as well. There must be a coordinated effort by members, conferences, and the NCAA to provide a unified message, despite the autonomy in governance of college sport. The decisions by member institutions may be in conflict with one another, but there should be coordination and governance to reduce message fragmentation in times of crisis. Institutions are autonomous, but they have chosen to be members of a particular conference and the NCAA, so unified communication should take priority.

An irony regarding the messaging surrounding the response to COVID-19 was that the Ivy League's statement was released earlier than the NBA's or NHL's and paralleled the straightforwardness that the other sports put out. They similarly cited unanimity supporting the response and offered context to the consultation they received in making their decision. The subsequent cancellation and communication, essentially, should be marked as a model when compared with other leagues, but is likely overlooked because of the Ivy League's association with the larger NCAA response. The NCAA and its members have demonstrated a clear need to develop a better and more uniform communication strategy within the organization so there can be clear and coherent communication to the public. The pandemic crisis presented society with uncertain times, but the mixed messages from the NCAA and its members creates more uncertainty and confusion within the arena of college sport.

\section{References}

American Athletic Conference. (2020, March 12). American Athletic Conference announces cancellation of competition and championships for 2019-20 [Press release]. TheAmerican.org. Retrieved from https://bit.ly/2Хухуср 
Big 12 Conference. (2020a, March 12). Big 12 Conference announces additional measures [Press release]. Big12sports.com. Retrieved from https://bit.ly/2AhZLvS

Big 12 Conference. (2020b, March 29). Big 12 statement on athletics activities [Press release]. Big12sports.com. Retrieved from https://bit.ly/2ZGyduY

Big East Conference. (2020, March 12). Big East cancels all spring sport championships [Press release]. BigEast.com. Retrieved from https://bit.ly/2M2ZFLl

Boone, K. (2020). Mid-American Conference cancels postseason tournaments eight sports, changes basketball format. CBSSports.com. Retrieved from https://bit.ly/3d6cWPm

Brown, R.S. (2004). Sport and the healing of America after 9/11. In R. Denton (Ed.), Language, symbols, and the media: Communication in the aftermath of the World Trade Center attack (pp. 117-127). New Brunswick, NJ: Transaction Publishers.

Cancian, D. (2020, April 15). Dr. Fauci says sports can return this summer but only if games are played behind closed doors. Newsweek. Retrieved from https://bit.ly/ 2X7KN4F

Chass, M. (2001, September 12). BASEBALL; Selig, in a Sense of Mourning, Cancels Baseball Games. New York Times. Retrieved from https://nyti.ms/2yDdsVT

Chidester, P.J. (2009). "The Toy Story of Life": Myth, sport, and the mediated reconstruction of the American hero in the shadow of the September 11 terrorist attacks. Southern Communication Journal, 74(4), 352-372. doi:10.1080/10417940802510365

Cloninger, D., \& Needelman, J. (2020, May 12). Coronavirus could drastically change football season for USC, Clemson fans, Here's how. The Post and Courier. Retrieved from https://bit.ly/3d8zwH3

Composition and Sport Sponsorship of the NCAA Membership. (2020). Retrieved from https://bit.ly/36E9Srk

Coombs, W.T., Holladay, S.J., \& Claeys, A.S. (2016). Debunking the myth of denial's effectiveness in crisis communication: context matters. Journal of Communication Management, 20(4), 381-395. doi:10.1108/JCOM-06-2016-0042

Cox, M. (2020). Keep baseball going. Retrieved from https://bit.ly/3c9ncoG

Dellenger, R. (2020, March 12). Inside the eerie scene of college basketball's final game of the season. Sports Illustrated. Retrieved from https://bit.ly/3c6E5Al

Dodd, D. (2020, April 15). Commissioners tell VP Mike Pence college sports won't be back until students return to campus. CBSSports.com. Retrieved from https://bit.ly/2ZE00fH

Duncan, C. (2020, May 9). Will coronavirus cancel college football this fall? It depends, NCAA president says. Miami Herald. Retrieved from https://hrld.us/ 2X6GVAX

Gmoser, J. (2020, April 22). How Anthony Fauci became the nation's top disease expert. Business Insider. Retrieved from https://bit.ly/2ZGIDeb

Goldman, T. (2020, April 15). Major League Baseball joins the fight against coronavirus in a big way. NPR.org. Retrieved from https://n.pr/3cecddK

Golliver, B. (2020, March 12). Inside the NBA's coronavirus response and its decision to suspend season. Washington Post. Retrieved from https://wapo.st/3gtKfhi

Hamby, P. (2020, April 15). Peter Hamby interviews Dr. Anthony Fauci. Good Luck America. Retrieved from https://www.youtube.com/watch?v=kpjzVJnPELQ\& feature=youtu.be

Harding, E. (2020, May 12). Fall semester of intercollegiate athletics suspended. Eastbaypioneers.com. Retrieved from https://bit.ly/2XGtpDs

Ivy League Athletics. (2020, March 11). Ivy League to cancel all athletic events through the remainder of the spring [Press release]. IvyLeague.com. Retrieved from https://bit.ly/ 3c9i2Jl

King, P. (1993, November 22). The blackest Sunday: Pete Rozelle's decision to play NFL games on the weekend of JFL's death still bothers players who took the field. Sports Illustrated. Retrieved from https://cnn.it/2AbBKXt 
King, P. (2014, July 15). Paul Tagliabue's post-9/11 correspondence. Sports Illustrated. Retrieved from https://bit.ly/3eswwpk

Megargee, S. (2020, May 11). Budget crunch could impact how college teams opt to travel. Chattanooga Times Free Press. Retrieved from https://bit.ly/2AZWmCm

Mell, R. (2020, March 12). Let them play? PGA Tour's coronavirus response too sluggish, not forceful enough. GolfChannel.com. Retrieved from https://bit.ly/2TJ42iR

Mirabito, T. (2013). Reporting crisis: An analysis of the New York Times' sports section following the tragedies of September 11, 2001 (Doctoral dissertation 1762). University of Tennessee database, Knoxville, Tennessee.

National Basketball Association. (2020, March 11). NBA to suspend season following Wednesday's games [Press release]. NBA.com. Retrieved from https://on.nba.com/ 2XD1AeT

National Collegiate Athletic Association. (2019). Consolidated Financial Statement. Retrieved from https://go.aws/3gs1cbL

National Collegiate Athletic Association. (2020a, March 11). NCAA President Mark Emmert's statement on limiting attendance at NCAA events [Press release]. NCAA.org. Retrieved from https://bit.ly/2B7SvU1

National Collegiate Athletic Association. (2020b, March 12). NCAA cancels remaining winter and spring championships [Press release]. NCAA.org. Retrieved from https://bit. ly/2TFRx7O

NCAA Academic and Membership Affairs Staff. (2019). 2019-20 NCAA Division I Manual. Indianapolis, IN: National Collegiate Athletic Association.

NCAA v. Board of Regents of the Univ. of Oklahoma, 468 U.S. 85 (1984)

Nesbitt, A. (2020, March 27). The NBA once again shows other leagues how to handle business during coronavirus. USA Today. Retrieved from https://bit.ly/36zszfD

Nicholas, P., \& Friedman, U. (2020, April 14). Anthony Fauci, lightning rod. The Atlantic. Retrieved from https://bit.ly/31079FY

Pac-12 Conference. (2020, March 12). Pac-12 statement on student-athlete athletic activities [Press release]. Pac-12.com. Retrieved from https://bit.ly/3etjO9t

Prewitt, A. (2020, April 2). The NHL's big test: Inside the league's pandemic response. Sports Illustrated. Retrieved from https://bit.ly/2TIDzSM

Professional Golf Association. (2020, March 12). PGA Tour statement regarding cancellation of THE PLAYERS Championship and upcoming PGA TOUR events [Press release]. PGATour.com. Retrieved from https://bit.ly/3eoFofl

Shatel, T. (2013, November 22). Day after 1963 tragedy, NU-OU played after Bobby Kennedy's OK. World-Herald. Retrieved from https://bit.ly/3ej2DHI

Southeastern Conference. (2020, March 14). SEC suspends all athletics activity through April 15 [Press release]. SECSports.com. Retrieved from https://bit.ly/3c9iRBV

Sun Belt Conference. (2020, March 12). Sun Belt statement on spring sports competitions [Press release]. SunBeltSports.org. Retrieved from https://bit.ly/2M0eGOd

Vaccaro, M. (2020, March 12). The day coronavirus sent the sports world into darkness. New York Post. Retrieved from https://bit.ly/2M5jFx2

Zillgitt, J. (2020, March 21). NBA draws ire as players tested for coronavirus amid national kit shortage. USA Today. Retrieved from https://bit.ly/2X4BAKt 